\title{
PENGARUH GAYA KEPEMIMPINAN, PENGEMBANGAN SDM, DAN KOMUNIKASI TERHADAP KINERJA KARYAWAN PADA PT. MIDUK ARTA
}

\author{
Demak Claudia Yosephine Simanjuntak ${ }^{1),}$ Nabillah Pratiwi 1), Melva R.Hutahaean 1), \\ ${ }^{1)}$ Fakultas Ekonomi, Universitas Prima Indonesia \\ E-mail : claudiayoseph8@gmail.com
}

\begin{abstract}
Abstrak
Penelitian ini bertujuan untuk mengetahui pengaruh gaya kepemimpinan, pengembangan sumber daya manusia dan komunikasi terhadap kinerja karyawan pada PT. Miduk Arta yang terletak di jalan Sisingamangaraja km 6,3 No.40 Medan. Populasi penelitian berjumlah 100 responden. Sampel penelitian berjumlah 80 responden. Pengambilan sampel menggunakan rumus slovin. Teknik pengumpulan data yang digunakan adalah kuesioner yang pengukurannya menggunakan skala Interval dan diolah secara statistik menggunakan metode analisis regresi berganda dengan persamaan $\mathrm{Y}=$ $\mathrm{a}+\mathrm{b}_{1} \mathrm{X}_{1}+\mathrm{b}_{2} \mathrm{X}_{2}+\mathrm{b}_{3} \mathrm{X}_{3}+\mathrm{e}$. Hasil penelitian menunjukkan bahwa secara simultan Gaya Kepemimpinan, Pengembangan SDM dan Komunikasi berpengaruh positif dan signifikan terhadap Kinerja Karyawan di PT. Miduk Arta. Diharapkan peneliti selanjutnya dapat menambahkan variabel yang diteliti agar hasilnya menjadi lebih baik lagi.
\end{abstract}

Keywords: Gaya Kepemimipinan, Pengembangan SDM, Komunikasi, Kinerja Karyawan. 


\section{PENDAHULUAN}

Manajemen sumber daya manusia pada umumnya sangat diperlukan oleh setiap instansi perusahaan maupun pemerintah, SDM dikaji untuk menentukan suatu hasil kinerja yang ditujukan untuk tujuan akhir dari setiap perintah pelaksaan tugas-tugas yang ditetapkan oleh pimpinan, dalam hal ini tentu kita ketahui secara luas bahwa SDM sangatlah diperlukan, oleh karena itu dengan peningkatan kualitas SDM perlu adanya kecakapan dalam gaya kepemimpinan seorang manajer dalam melakukan pengembangan SDM, serta melatih kecakapan dalam berkomunikasi guna untuk meningatkan hasil kinerja setiap karyawan.

Gaya kepemimpinan yang cerdas memiliki cara atau gaya tersendiri dalam memimpin PT. Miduk Arta, tergantung bagaimana seorang pemimpin dapat melaksanakan tugasnya dengan baik, permasalahan yang terjadi pada perusahaan ini menyangkut gaya atau cara pemimpin dalam memimpin karyawannya, dimana dalam hal ini terjadi sifat otokrat pemimpin dalam menyelesaikan setiap tugas dan kurang memperhatikan pengembangan karyawannya.

Pengembangan sumber daya manusia akan berpotensi untuk digunakan saat ini maupun untuk tujuan masa depan, pengembangan SDM dilakukan guna meningkatkan pengetahuan dan kemampuan setiap karyawan tentang pekerjaannya. . PT. Miduk Arta mengalami masalah dalam menjalankan tata cara mengembangkan karyawan di karenakan masih banyak karyawan perusahaan berpendidikan rendah, kurangnya rotasi jenjang karir sehingga banyak karyawan yang mencari pekerjaan pada perusahaan lain.

Komunikasi merupakan proses penyampaian informasi secara langsung dan tidak langsung. Komunikasi yang terjadi pada PT. Miduk Arta ini tentunya kesalahan dalam menjalankan tugas. Dalam hal ini kesalahan terjadi dalam beberapa divisi bagian, hal ini sulit di hindari oleh setiap karyawan dalam menyelesaikan tugas masing-masing dimana kurangnya komunikasi antara atasan dan karyawan ataupun antara karyawan dengan karyawan.

PT. Miduk Arta beralamat di Jalan Sisingamangaraja $\mathrm{Km} \quad 6,3$ No.40 Medan, Perusahaan ini bergerak dalam bidang penjualan jasa transportasi kepada pertamina untuk mendistribusikan bahan bakar minyak seperti bensin dan solar ke SPBU. Berdasarkan informasi yang diperoleh diketahui bahwa PT. Miduk Arta tidak mencapai target yang ditetapkan pihak perusahaan sebelumnya, presentase yang paling rendah berada pada bulan September 2018, hal ini disebabkan kendala kualitas perbaikan mesin angkutan oleh bagian mekanik yang tidak sesuai dengan yang di inginkan pihak perusahaan, menyebabkan beberapa angkutan tidak dapat beroperasi dengan baik. Sedangkan realisasi pencapaian target tertinggi berada pada bulan Febuari 2018, dimana hal ini disebabkan kualitas barang yang di hasilkan sangat bagus dan angkutan operasi yang digunakan di perbaiki dengan maksimal sehingga mesin serta peralatan yang digunakan masih dengan kualitas layak dipakai.

\section{TINJAUAN PUSTAKA}

Gaya kepemimpinan adalah suatu pola perilaku berulang yang diperlihatkan oleh seorang pemimpin, penelitian perilaku pemimpin memeriksa gaya-gaya kepemimpinan alternative, dengan tujuan untuk menentukan gaya kepemimpinan mana yang berfungsi (Schermerhorn, 2010:270). Edison (2017:91), Gaya kepemimpinan adalah cara pemimpin bertindak dan atau bagaimana ia mempengaruhi anggotanya untuk mencapai tujuan tujuan tertentu, para pakar menilai bahwa gaya kepemimpinan setiap orang berbeda. Berdasarkan beberapa pengertian di atas dapat disimpulkan bahwa gaya kepemimpinan merupakan perilaku pemimpin dalam bertindak dalam mempengaruhi karyawannya untuk mencapai tujuan yang telah ditentukan. Semakin baik gaya kepemimpinan seorang pemimpin akan 
memberikan pengaruh besar kepada karyawannya.

Pengembangan SDM adalah penyiapan manusia atau karyawan untuk memikul tanggung jawab lebih tinggi dalam organisasi atau perusahaan (Samsudin 2010:107). Sikula (2011:105), Pengembangan SDM adalah suatu proses pembelajaran jangka panjang menggunakan suatu prosedur yang sistematis dan terorganisir dengan mana manajer belajar pengetahuan konseptual dan teoritis untuk tujuan umum. Berdasarkan beberapa pengertian di atas dapat disimpulkan bahwa pengembangan sumber daya manusia merupakan cara yang dilakukan untuk mempersiapkan karyawan yang memiliki kemampuan sesuai dengan yang diharapkan perusahaan. Semakin berkembang SDM karyawan semakin meningkat kinerjanya karena dapat membantu meningkatkan pengerjaan beban-beban kerja karyawan tersebut.

Komunikasi juga dapat berarti adanya kesamaan makna antara komunikator dan komunikan dengan tujuan mengubah sikap, opini, atau pandangan/ perilaku orang lain tentang pesan yang di sampaikan (Effeny 2016:455). Bangun (2012:372), Komunikasi merupakan salah satu tugas penting manajer untuk mencapai hasil kerja yang baik dalam organisasi.

Berdasarkan beberapa pengertian di atas dapat disimpulkan bahwa komunikasi adalah cara seseorang dengan orang lain dalam hal penyampaian pesan agar lebih mudah dipahami dan dimengerti. Komunikasi yang baik yaitu dua arah antara pimpinan dengan karyawannya sehingga bisa saling memahami dan meminimalisir terjadinya kesalahpahaman.

Kinerja adalah suatu hasil yang di capai seorang dalam melaksanakan tugas tugas yang di berikan kepadanya yang di dasarkan atas kecakapan, pengalaman, dan kesanggupan serta waktu (Supriyono 2010:281). Rivai (2018:269), Kinerja merupakan perilaku nyata yang di tampilkan setiap orang sebagai prestasi kerja yang dihasilkan oleh pegawai sesuai dengan perannya dalam organisasi. Berdasarkan beberapa pengertian di atas dapat disimpulkan bahwa kinerja karyawan adalah hasil yang telah diperoleh karyawan berdasarkan beban-beban kerjanya.

\section{METODE PENELITIAN}

Populasi dalam penelitian ini adalah karyawan PT.Miduk Arta yang berjumlah 100 orang. Sampel dalam penelitian ini adalah 80 orang karyawan. Penelitian ini menggunakan uji validitas dan uji realibilitas dengan responden sebanyak 30 orang karyawan berdasarkan jumlah responden minimal yang dapat digunakan.

Uji asumsi klasik yang digunakan dalam penelitian ini adalah uji normalitas, uji multikolinearitas, dan uji heteroskedastisitas. Setelah lolos uji asumsi klasik dilanjutkan dengan uji regresi linier berganda, uji koefisien determinasi, uji $\mathrm{F}$ (simultan) dan uji $\mathrm{t}$ (parsial).

\section{HASIL DAN PEMBAHASAN}

Berdasarkan hasil pengolahan data, maka diperoleh uji validitas dilakukan di cabang PT. Miduk Arta yang terletak di Kota Siantar dengan jumlah responden yaitu 30 orang, $r_{\text {hitung }}>r_{\text {tabel }}(0,3610)$ maka pertanyaan dinyatakan valid.

Hasil uji realibitas diketahui bahwa untuk ke-24 pertanyaan kuesioner memiliki nilai Cronbach's Alpha if Item Deleted > 0,60 maka dapat disimpulkan bahwa semua pertanyaan kuesioner reliabel.

Hasil uji asumsi klasik yaitu uji normalitas diperoleh nilai signifikan 0,067 > 0,05 , sehingga berdasarkan pengujian Kolmogorov smirnov menunjukkan data berdistribusi normal. Data pada grafik histogram data riil membentuk garis kurva cenderung simetri (U) tidak melenceng ke kiri atau pun ke kanan maka dapat dikatakan data berdistribusi normal. Grafik Normalitas P-P Plot terlihat data menyebar disekitar garis diagonal, penyebarannya sebagian besar mendekati garis diagonal. Hal ini berarti bahwa data berdistribusi normal. 
Pada uji multikolinearitas diperoleh nilai tolerance gaya kepemimpinan, pengembangan SDM dan komunikasi > 0,1 sedangkan nilai VIF untuk variabel-variabel tersebut <10. Dengan demikian pada uji multikolinearitas tidak terjadi korelasi antar variabel bebas.

Pada uji heteroskedastisitas diperoleh grafik yang menunjukkan titik-titik menyebar dengan pola yang tidak jelas baik di atas maupun di bawah angka nol (0) pada sumbu Y, tidak berkumpul di satu tempat sehingga dari grafik scatterplot dapat disimpulkan bahwa tidak terjadi heteroskedastisitas pada model regresi. Berdasarkan uji gletger diperoleh nilai signifikan dari gaya kepemimpinan sebesar $0,368>0,05$, pengembangan SDM 0,613> 0,05 dan komunikasi sebesar 0,596>0,05 bahwa tidak terjadi masalah heteroskedastisitas.

Berdasarkan hasil perhitungan regresi linear berganda, diperoleh:

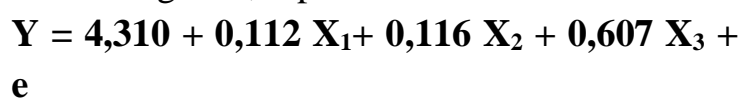
$Y=4,310+0,112 X_{1}+0,116 X_{2}+0,607 X_{3}+$ e

Penjelasannya adalah:

1. Konstan 4,310

Apabila gaya kepemimpinan, pengembangan SDM dan komunikasi mengalami konstan maka kinerja karyawan pada sebesar 4,310satuan.

2. Koefisien regresi gaya kepemimpinan 0,112

Setiap kenaikan gaya kepemimpinan sebesar satu satuan akan meningkatkan kinerja karyawan sebesar 0,112 satuan dengan anggapan variabel lainnya tetap.

3. Koefisien regresi pengembangan SDM 0,116

Setiap kenaikan pengembangan SDM sebesar satu satuan akan meningkatkan kinerja karyawan sebesar 0,116 satuan dengan anggapan variabel lainnya tetap.

4. Koefisien regresi komunikasi 0,607

Setiap kenaikan komunikasi sebesar satu satuan akan meningkatkan kinerja karyawan sebesar 0,607 satuan dengan anggapan variabel lainnya tetap.
Hasil uji koefisien determinasi dilihat dari nilai Adjusted $R$ Square sebesar 0,829 hal ini berarti $82,9 \%$ bahwa kinerja karyawan yang dapat dijelaskan oleh disiplin kerja, stress kerja dan kepemimpinan sedangkan sisanya sebesar $17,1 \%$ dijelaskan oleh variabel lain yang tidak diteliti pada penelitian ini.

\section{Tabel 1 Hasil Uji Simultan (Uji F)}

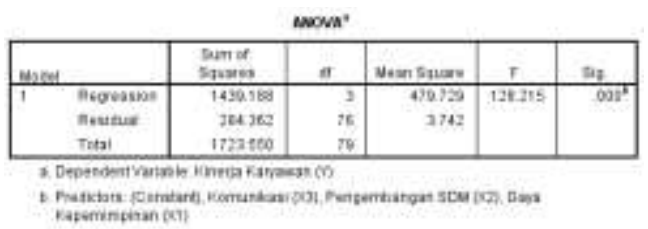

Sumber : Hasil Penelitian, 2020 (Data diolah)

Hasil pengujian simultan (Uji F) diperoleh nilai $F_{\text {hitung }}(128,215)>F$ tabel $(2,72)$ dan probabilitas signifikansi $0,000<0,05$, berarti bahwa secara simultan Gaya Kepemimpinan, Pengembangan SDM dan Komunikasi berpengaruh positif dan signifikan terhadap Kinerja Karyawan di PT.Miduk Arta.

Tabel 1 Hasil Uji Parsial (Uji t)

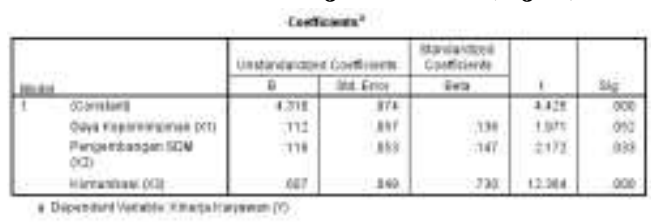

Sumber : Hasil Penelitian, 2020 (Data diolah)

Hasil dari pengujian hipotesis secara parsial (uji t) dapat dijelaskan sebagai berikut :

1. Hasil perhitungan pengujian hipotesis secara parsial diperoleh nilai thitung < ttabel atau1,971< 1,990 dan signifikan yang diperoleh $0,052>0,05$, berarti bahwa Ha ditolak dan Ho diterima yaitu secara parsial Gaya Kepemimpinan tidak berpengaruh positif dansignifikan terhadap Kinerja Karyawan PT. Minduk Arta.

2. Hasil perhitungan pengujian hipotesis secara parsial diperoleh nilai thitung > ttabel atau2,172> 1,990 dan signifikan yang diperoleh $0,033<0,05$, berarti bahwa Ha diterima dan Ho ditolak yaitu secara 
parsial Pengembangan SDM berpengaruh positif dan signifikan terhadap Kinerja Karyawan PT. Minduk Arta.

3. Hasil perhitungan pengujian hipotesis secara parsial diperoleh nilai thitung > ttabel atau12,364> 1,990 dan signifikan yang diperoleh $0,000<0,05$, berarti bahwa Ha diterima dan Ho ditolak yaitu secara parsial Komunikasi berpengaruh positif dan signifikan terhadap Kinerja Karyawan PT. Minduk Arta.

\section{Pembahasan}

Berdasarkan analisa data mengenai pengaruh gaya kepemimpinan, pengembangan sdm, dan komunikasi terhadap kinerja karyawan pada PT. Miduk Arta, maka pembahasan hasilnya adalah:

Secara parsial Gaya Kepemimpinan tidak berpengaruh positif dan signifikan terhadap Kinerja Karyawan PT. Minduk Arta. Berdasarkan hasil tersebut dapat disimpulkan bahwa kinerja karyawan pada PT. Miduk Arta tidak dapat dipengaruhi oleh faktor internal gaya kepemimpinan dan external gaya kepemimpinan. Meskipun seperti itu, Pimpinan seharusnya memberikan promosi jabatan, insentif dan reward lain agar karaywan memiliki semangat yang tinggi untuk bekerja ke arah yang lebih baik.

Secara parsial Pengembangan SDM berpengaruh positif dan signifikan terhadap Kinerja Karyawan PT. Minduk Arta. Berdasarkan hasil tersebut dapat disimpulkan bahwa pengembangan SDM berpengaruh positif dan signifikan terhadap kinerja karyawan di PT. Minduk Arta. Hal ini sejalan dengan penelitian yang dilakukan oleh Purnama, dkk (2020) yang menyatakan bahwa sistem pengembangan sumber daya manusia berpengaruh positif dan signifikan terhadap kinerja karyawan di PT. Arta Sedana Singaraja sebesar 65,8\%. Pengembangan SDM telah diterapkan dengan baik sehingga terbukti mampu meningkatkan kinerja karyawan. Proses perekrutan karyawan telah dilaksanakan dengan tepat, program pelatihan dan pengembangan telah dilaksanakan sesuai dengan kebutuhan karyawan dan kepentingan perusahaan, kesempatan pengembangan karir bagi karyawan telah diberikan secara adil, penilaian atau evaluasi kinerja telah dilakukan dengan tepat. Kondisi tersebut telah mendorong peningkatan kinerja karyawan yang ditunjukkan dengan adanya penyelesaian jumlah (volume) pekerjaan/tugas sesuai harapan (penyelesaian tugas secara kuantitas), serta terciptanya suasana kerja yang kondusif.

$$
\text { Secara parsial Komunikasi }
$$

berpengaruh positif dan signifikan terhadap Kinerja Karyawan PT. Minduk Arta. Berdasarkan hasil tersebut dapat disimpulkan bahwa komunikasi berpengaruh positif dan signifikan terhadap kinerja karyawan di PT. Minduk Arta.Komunikasi yang dilakukan oleh setiap Pemimpin terhadap karyawan PT. Minduk Arta sudah melakukan sesuai dengan indikator dari komunikasi yang diteliti dalam penelitian ini telah dilakukan dengan semestinya oleh Pimpinan. Hal ini sejalan dengan penelitian yang telah dilakukan oleh As'ad (2018) yang menyatakan bahwa komunikasi berpengaruh positif dan signifikan terhadap kinerja karyawan pada PT Titipan Mas Area V Makassar. Hal ini berarti semakin baik komunikasi, maka kinerja karyawan pada PT Titipan Mas Area V Makassar cenderung meningkat.

\section{KESIMPULAN DAN SARAN}

Adapun simpulan dari penelitian ini adalah secara simultan Gaya Kepemimpinan, Pengembangan SDM dan Komunikasi berpengaruh positif dan signifikan terhadap Kinerja Karyawan di PT.Miduk Arta. Secara parsial Gaya Kepemimpinantidak berpengaruh positif dan signifikan terhadap Kinerja Karyawan PT. Minduk Arta.

Secara parsial Pengembangan SDM berpengaruh positif dan signifikan terhadap Kinerja Karyawan PT. Minduk Arta. Secara parsial Komunikasi berpengaruh positif dan signifikan terhadap Kinerja Karyawan PT. Miduk Arta 


\section{REFERENSI}

Bangun.(2012). "Manajemen Sumber

Daya Manusia”. Bandung:

Erlangga.

Edison.(2017). "Manajemen Sumber

Daya Manusia”. Bandung:

Alfabeta.

Effendy.(2016). "Manajemen Sumber

Daya Manusia". Jakarta: Bumi

Aksara.

Rivai.(2018). "Perencanaan Dan

Pengembangan SDM". Bandung:

Alfabeta.

Samsudin.(2010). "Manajemen Sumber Daya

Manusia".

Bandung:Pustaka Setia.

Schermerhorn.(2010). "Perilaku

Organisasi”. Yogyakarta: Graha

Ilmu.

Sikula.(2011). "Manajemen SDM dalam organisasi publik dan bisnis”. Bandung:

Alfabeta.

Supriyono.(2010). "Manajemen

Penilaian Kinerja”. Yogyakarta: Gava Media. 